Assessment of impact of pesticides on water catchments and groundwater in some selected areas of Sri Lanka

by

Ambalanyaya Gamaethige Piyal Aravinna

Thesis submitted to the University of Sri Jayewardenepura for the award of the

Degree of Master of Philosophy in Chemistry on $29^{\text {th }}$ September 2006 


\section{Declaration}

The work described in this thesis was carried out by me under the supervision of Dr. Sudantha Liyanage, Dr. (Mrs.) Janitha A. Liyanage and Dr. A. M. Mubarak and a report on this has not been submitted in whole or in part to any university or any other institution for another Degree/Diploma.

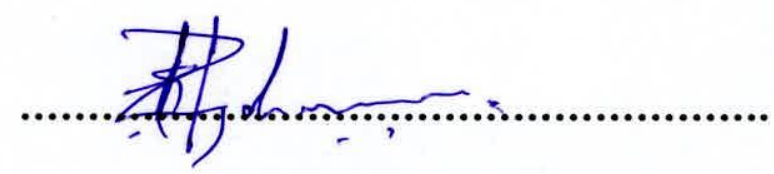

Signature of the candidate 
1. INTRODUCTION 1

2. LITERATURE REVIEW 5

2.1 Background of selected areas for pesticide impact assessment 5

2.1.1 Kalpitiya peninsula 5

2.1.1.1 Climate and geology $\quad 5$

2.1.1.2 Land use and agriculture 5

$\begin{array}{ll}\text { 2.1.1.3 Water usage of the area } & 7\end{array}$

2.1.1.4 Usage of pesticide 9

$\begin{array}{lll}2.1 .2 & \text { Walawe area } & 11\end{array}$

$\begin{array}{ll}\text { 2.1.2.1 Climatic condition } & 11\end{array}$

2.1.2.2 Physical and chemical properties of soil $\quad 12$

2.1.2.3 Main Irrigation system 15

2.1.2.4 Drinking water sources of the Walawe area 15

2.1.2.5 Usage of agricultural drainage water in Walawe area $\quad 16$

2.1.2.6 Land use of Walawe area 16

$\begin{array}{ll}\text { 2.1.2.7 Pesticide use } & 17\end{array}$

$\begin{array}{lll}2.2 & \text { Pesticide fate in the environment } & 21\end{array}$

2.2.1 Movement of pesticide in the environment 21

2.2.1.1 Movement of pesticide by air 21

2.2.1.2 Movement of pesticide by water 22

2.2.1.3 Movement of pesticide by crop removal 23 
2.2.2.2 Photo degradation

\subsection{Tools for Pesticide impact assessment on}

environmental component $\quad 34$

2.3.1 Approach to risk assessment tools $\quad 34$

2.3.2 Importance of PIRI as a simple risk indicator 35

2.3.3 Input parameters of PIRI 36

2.3.4 Theoretical background of PIRI 36

2.3.4.1 Pesticide load 36

2.3.4.2 Pesticide transport to groundwater $\quad 37$

2.3.4.3 Pesticide transport to surface water 38

2.3.4.4 Estimated concentration of pesticide $\quad 41$

2.3.4.5 Toxicity indexes $\quad 42$

2.3.4.6 Total pesticide load $\quad 43$

2.4 Applicable analytical methods for pesticide residual analysis 43

2.4.1 Extraction methods 43

2.4.2 Instrumentation 43

2.4.2.1 GC application for pesticide residue analysis $\quad 44$

2.4.2.2 HPLC application for analysis of pesticide residues $\quad 46$

2.4.2.3 Application of MSD $\quad 48$

2.4.3. Confirmation test for detected results 48

2.5 Toxicity measurement of pesticides 48 
2.5.1 Pesticides and human health

2.5.1.1 Acute (immediate) health effects $\quad 49$

2.5.1.2 Chronic (Long-term) health effects $\quad 50$

2.5.1.3 Health and environmental effects of certain classes of pesticides $\quad 50$

2.5.2 Toxicity endpoints 51

2.5.2.1 Lethal Dose $\left(\mathrm{LD}_{50}\right)$

2.5.2.2 Lethal Concentration $\left(\mathrm{LC}_{50}\right)$

2.5.2.3 Effective Concentration $\left(\mathrm{EC}_{50}\right)$

2.5.2.4 No Observed Adverse Effect Level (NOAEL) 53

2.5.2.5 Lowest Observed Adverse Effect Level (LOAEL) 53

2.5.3 Toxicological reference points for drinking water assessments $\quad 53$

2.5.3.1 Reference dose (RfD) $\quad 54$

2.5.3.2 Drinking-water equivalent level (DWEL) 55

2.5.3.3 Health advisories (HALs) $\quad 55$

2.5.3.4 Risk specific dose (RSD) $\quad 57$

2.5.4 Classifications and ranking chemicals on their acute toxicity $\quad 58$

3 METHODOLOGY 63 
3.1 Evaluation of sensitivity of PIRI as a pollution potential index 63

3.1.1 Effect of input parameter on groundwater pollution potential

3.1.1.1 Percentage of organic matter

3.1.1.2 Organic carbon partition coefficient and half life

3.1.1.3 Soil type

3.1.1.4 Recharge rate

3.1.2 Effect of input parameter on surface water pollution potential

3.1.2.1 Contribution of runoff and erosion on pollution potential

3.1.2.2 Buffer zone effect on pollution potential 68

3.1.2.3 Effect of land slope on pollution potential 69

3.1.2.4 Effect of pesticide load on pollution potential 70

3.1.3 Data handling of PIRI 71

3.1.3.1 Difficulties of data handling for mosaic of land uses 71

3.1.3.2 Estimation of pesticide load on mosaic of land uses

3.1.3.3 Estimation for seasonal soil loss

3.1.3.4 Estimation of toxicity parameter for PIRI

3.2 Estimation of mobility risk and toxicity risk for commonly used pesticides on groundwater and surface water using PIRI 74 
$\begin{array}{lll}3.2 .1 & \text { Site selection } & 74\end{array}$

$\begin{array}{lll}\text { 3.2.2 PIRI input data } & 75\end{array}$

3.2.2.1 Soil parameters of the selected area $\quad 75$

$\begin{array}{ll}\text { 3.2.2.2 Field data } & 75\end{array}$

3.2.2.3 Climatic parameters for the selected period 76

3.2.2.4 Input parameters of catchments in Walawe area $\quad 76$

$\begin{array}{ll}\text { 3.2.2.5 Pesticide input parameters } & 77\end{array}$

$\begin{array}{ll}\text { 3.2.2.6 Time period } & 78\end{array}$

$\begin{array}{lll}\text { 3.3 Water quality monitoring } & 79\end{array}$

$\begin{array}{lll}3.3 .1 & \text { Walawe area } & 79\end{array}$

$\begin{array}{ll}\text { 3.3.1.1 Monitoring of surface water reservoirs } & 79\end{array}$

$\begin{array}{ll}\text { 3.3.1.2 Field trial } 1 & 79\end{array}$

$\begin{array}{ll}\text { 3.3.1.3 Field trial } 2 & 80\end{array}$

$\begin{array}{ll}\text { 3.3.2 Kalpitiya area } & 82\end{array}$

3.3.2.1 Initial monitoring program $\quad 82$

3.3.2.2 Field trial $3 \quad 83$

3.3.3 Handling of samples $\quad 88$

3.4 Analytical methods used for pesticide residual analysis $\quad 88$

$\begin{array}{ll}\text { 3.4.1 Apparatus and materials } & 88\end{array}$

$\begin{array}{ll}\text { 3.4.1.1 Equipment } & 88\end{array}$

$\begin{array}{ll}\text { 3.4.1.2 Glassware } & 89\end{array}$

$\begin{array}{ll}\text { 3.4.1.3 Reagents } & 90\end{array}$ 
3.4.2.1 Stock standard solutions $\quad 91$

3.4.2.2 Intermediate standard solution $\quad 92$

$\begin{array}{ll}\text { 3.4.2.3 Working solution } & 92\end{array}$

3.4.2.4 Calibration standard $\quad 92$

3.4.2.5 Solvent for standard solution $\quad 92$

3.4.3 Sample preparation $\quad 92$

3.4.3.1 Sample extraction $\quad 92$

3.4.3.2 Florisil column cleanup procedure $\quad 94$

$\begin{array}{lll}3.4 .4 & \text { Instrumentation } & 95\end{array}$

3.4.4.1 HPLC operating conditions 95

3.4.4.2 GC operating conditions 95

3.4.4.3 GC/ MS operating conditions 97

3.4.5 Compound identification and quantification $\quad 97$

$\begin{array}{ll}\text { 3.4.5.1 Identification of analytes } & 97\end{array}$

3.4.5.2 Quantification of analytes $\quad 98$

3.4.6 Method detection limits $\quad 100$

$\begin{array}{ll}\text { 3.4.6.1 Definition } & 100\end{array}$

3.4.6.2 Determination procedure for MDL $\quad 100$

$\begin{array}{lll}3.4 .7 & \text { Recovery studies } & 101\end{array}$

$\begin{array}{ll}\text { 3.4.8 Confirmation of detected compounds } & 102\end{array}$

3.4.8.1 Confirmation of detected pesticide by HPLC 102 
4. RESULTS

4.1 PIRI Predictions

4.1.1 Groundwater risk

4.1.2 Surface Water risk

4.2 Results of water quality monitoring

4.2.1 Walawe area

4.2.1.1 Surface water reservoirs

4.2.1.2 Monitoring results of field trial 1

4.2.1.3 Monitoring results of field trial 2

4.2.2 Kalpitiya area

4.2.2.1 Results of initial monitoring program

4.2.2.2 Results of field trial 3

\subsection{Analytical parameters of selected pesticides}

4.3.1 Method detection limits

4.3.1.1 Method detection limits of analysed pesticides by HPLC

4.3.1.2 Method detection limits of analysed pesticides by GC

4.3.2 Recoveries of analysed pesticides 
5.1 Comparison of actual risk with PIRI Prediction

5.1.1 Ground water

5.1.2 Surface water

5.2 Dissipation of pesticides on field

5.2.1 Carbamate pesticides

5.2.1.1 Carbofuran

5.2.1.2 Carbaryl

5.2.2 Organophosparous pesticides

5.2.2.1 Chlorpyrifos

5.2.2.2 Dimethoate

5.2.2.3 Diazinon

5.2.3 Other pesticide groups

5.2.3.1 Imidacloprid

5.2.3.2 Oxyfluorfen

5.3 Effect of indiscriminate pesticide application on water pollution

5.4 Effect of agricultural practices on pesticide leaching

5.4.1 Irrigation

5.4.2 Organic carbon content of soil

5.5 Lateral movement of pesticides

5.6 Movement of pesticides to surface water body 
5.7 Comparison of detected residue levels with drinking water guide lines $\quad 153$

6 CONCLUTION 155

7 REFERENCES 157

8 APPENDICES 165

$\begin{array}{ll}\text { Appendix } 1 & 165\end{array}$

$\begin{array}{ll}\text { Appendix } 2 & 175\end{array}$

$\begin{array}{ll}\text { Appendix } 3 & 176\end{array}$

Appendix 4

$\begin{array}{ll}\text { Appendix } 5 & 180\end{array}$ 


\section{LIST OF TABLES}

1 Physical and chemical properties of surface soil of Kalpitiya 6

2 Physical and chemical properties of major soil types of Walawe area

3 Summery of pesticide usage by farmers in the Kalpitiya peninsula and Walawe area

$4 \quad$ Half life of selected pesticides under various degradation pathways

$5 \quad$ Score system and name of risk category $\quad 42$

6 USEPA pesticide product toxicity and toxicity categories $\quad 59-60$

$7 \quad$ Toxicity categories for aquatic systems $\quad 61$

$8 \quad$ PAN acute toxicity categories and equivalences $\quad 61-62$

9 Effect of soil type on attenuation factor and estimated recharge rate $\quad 66$

10 Soil type and soil organic mater of selected area 75

$\begin{array}{lll}11 & \text { Field data of selected areas } & 75\end{array}$

12 Climatic data for the selected period 76

13 Related reservoir data and catchments data used for risk assessment 76

14 Environmental half life $\left(\mathrm{t}_{1 / 2}\right)$, defined toxicity $\left(\mathrm{T}_{\mathrm{df}}\right)$, organic carbon partition coefficient (Koc) and application data of pesticide.

15 Details of pesticides application $\quad 80$

16 Pesticide application and first irrigation time $\quad 81$

17 Details of pesticide product $\quad 86$

18 Pesticides and concentration ranges used for calibration 99-100 
19 Predicted risk of mobility and toxicity

20 Attenuation factor of the selected pesticides

$105-106$

21 Detected pesticide and their residue level in field well samples

22 Chromatographic conditions and Method Detection Limits of

HPLC method

23 Method detection limits and retention time of GC channels

24 Recoveries of analysed pesticides

$122-123$

25 Pesticides and retention order in GC/MSD

26 PIRI prediction and actual detection for ground water

$139-140$

27 PIRI prediction and actual detection for surface water 


\section{LIST OF FIGURS}

1 Sketch map of Kalpitiya peninsula $\quad 7$

2 Annual rain fall in Kalpitiya 8

3 Hydrological cross section of Kalpitiya peninsula 10

$4 \quad$ Annual rainfall distribution in Walawe area 11

$5 \quad$ Sketch map of Walawe special area $\quad 14$

$6 \quad$ Land use of Walawe special area in $2002 \quad 17$

$7 \quad$ Fate of pesticide in environment 21

$8 \quad$ Metabolic maps of pesticides $\quad 30-34$

9 Effect of percentage of organic matter on AF 64

10 Effect of $t_{1 / 2}$ on attenuation factor $\quad 65$

11 Estimated recharge rates for soil type $\quad 67$

12 Contribution of surface runoff and erosion on total pollution potential 68

13 Effect of width of buffer zone on surface water 69

14 Effect of land slope on runoff pathway of pollution potential $\quad 70$

15 Define toxicity and NOAEL for several pesticides 74

16 Sketch map of site used for field trial 1

17 Sketch map of plots applied with pesticide $\quad 84$

18 Structure of irrigation well 85

$19 \quad$ Mixing of carbofuran with dry sand $\quad 87$

20 Groundwater mobility impact for Walawe area 107

21 Groundwater mobility impact for Kalpitiya $\quad 108$ 
22 Groundwater toxicity impact for Walawe area

23 Groundwater toxicity impact for Kalpitiya area

24 Surface water toxicity risk on Metigath Wewa and Kattakaduwa Wewa

25 Surface water mobility risk on Metigath Wewa and Kattakaduwa Wewa

26 Changes of Chlorpyrifos residue level along drainage line

27 Changes of Dimethoate residue level along drainage line

28. Changes of $2,4 \mathrm{D}$ residue level along drainage line

29 Changes of MCPA residue level along drainage line

30 Detection profile of Carbofuran in FI- wells

31 Detection profile of Chlorpyrifos in FI- wells

32 Detection profile of Dimethoate in FI- wells

33 Liquid chromatograms of mixed standard solution

34 Liquid chromatograms of spiked water samples

35 Gas chromatograms

36 UV spectra of pesticides analysed by HPLC

37 Total ion chromatogram of GC/MSD

38 Mass spectrum of the standard pesticides

39 Leakage of irrigation water from damaged tubes

40 Effect of irrigation on groundwater pollution potential (Kalpitiya)

41 Maximum residue levels of pesticides and their drinking water guidelines 


\section{ACKNOWLEDGEMENT}

I am greatly indebted to my supervisors, Dr. A. M. Mubarak, Director, Industrial Technology Institute and Dr. (Mrs.) Janitha A. Liyanage, senior lecturer, Department of Chemistry, University of Kelaniya, Kelaniya for valuable advises, continued guidance, encouragement and criticism given me to complete this project successfully.

I would like to express my cordial thanks to Dr. Sudantha Liyanage, Department of Chemistry, University of Sri Jayewardenepura, Gangodawila, Nugegoda for taking me as his student for my academic proceedings.

I cordially thank Dr. A. M. Mubarak, Director and Mrs. Sharmini Wickramaratne, Technical manager, CML for providing me the opportunity to carry out this study at ITI. I wish to express my thanks International Atomic Energy Agency for funding the project. I wish to thank to Mr. Gamini Gunawardena, ITI for his technical assistances.

I offer my grateful thank to Dr. Rai S. Kookana and Ray L. Correll, CSIRO, Australia for their assistance to handle the PIRI model.

I wish to thank Mr. Bathika Priyantha for his assistant in field works and I wish to thank all members of ITI who participated in the accomplishment of this research study.

I thank to my dear wife for her assistance given me by helping for field work and my day to day activities during this period.

Finally I wish to thank my family members and friends for their help during this period. 


\title{
Assessment of impact of pesticides on water catchments and groundwater in some selected areas of Sri Lanka
}

\section{Ambalanyaya Gamaethige Piyal Aravinna}

\begin{abstract}
Environmentalists and general community are concerned about the impact of pesticides on the environment. Systematic methods of assessment of potential risk of pesticides to environmental components can serve as valuable tools in decision-making and policy formulation. The objectives of this study were; to rank commonly used pesticides in Sri Lanka according to their pollution potential on surface and groundwater using an indicator model, field residual monitoring to measure actual risk on surface and groundwater and compare with the observed risk with prediction of indicator model.
\end{abstract}

High recharge rate due to excessive irrigation, sandy soil with low organic matter and shallow water table depth are features of the Kalpitiya area which are expected to contribute to high risk on groundwater. Some surface water reservoirs which are fed by agricultural catchments, located in the Walawe area are used as sources for public water supplies therefore the surface water pollution potential is high. Kalpitiya peninsula and Walawe area were selected for the study.

Relative risk of pesticide in terms of mobility and toxicity on surface and groundwater were assessed using an indicator model namely Pesticide Impact Rating Index. Shallow domestic wells which were located around agricultural plots of both Walawe and Kalpitiya areas and the man made reservoirs in Walwe area were monitored for commonly used pesticides. According 
to PIRI prediction; out of commonly used pesticides in Kalpitiya area, Carbofuran and Dimethoate fall into "Extremely high" risk category and Imidaclorpride falls into "Very high" risk category for groundwater contamination potential. Out of commonly used pesticides in Walawe area Carbofuran and 2,4D fall into Extremely high and Very high risk categorise, respectively for groundwater mobility. The mobility risk of the selected pesticides for surface water of Kattakaduwa Wewa and Metigath Wewa is very low.

Applied pesticide on agricultural fields at the recommended rate(department of agriculture), were not found in wells which were located, 5-10 m away from the agricultural plots in Kalpitiya where Diazinon, Carbaryl, Methomyl, Imidacloprid, Fenthion, Captan, Carbofuran, Dimethoate, Chlorpyrifos and Oxyfluorfen are widely used and 1 to $3 \mathrm{~m}$ outside of the paddy fields in Walawe area where 2, 4 D, MCPA, Propanil, Diazinon, Carbofuran, Dimethoate, Chlorpyrifos, Oxyfluorfen and Fenthion are widely used. Residues of commonly used Pesticide were not detected in the reservoirs of Kattakaduwa Wewa, Metigath Wewa and Pathirana Wewa which are fed by either $100 \%$ drainage water or the reservoir of Habaralu Wewa, Kiri-ibban Wewa, Chandrika Wewa and Sooriya Wewa which are fed mainly by nonagricultural drainage. According to the field trials, when pesticides applied at the recommended rate and agricultural plots were irrigated at the average rate of $20 \mathrm{~mm} /$ day, Dimethoate, Carbofuran, and Chlorpyrifos leached to $3 \mathrm{~m}$ water table of Kalpitiya at $24 \pm 4$ days, $25 \pm 3$ days and $35 \pm 6$ days after application of each pesticide respectively but Diazinon, Carbaryl, Methomyl, Imidacloprid, Fenthion, Captan, and Oxyfluorfen are not detected. The result from the case studies matched with the PIRI prediction, $100 \%$ for surface water and $74 \%$ for and groundwater. 